\title{
The effect of misleading surface temperature estimations on the sensible heat fluxes at a high Arctic site - the Arctic Turbulence Experiment 2006 on Svalbard (ARCTEX-2006)
}

\author{
J. Lüers and J. Bareiss \\ Department of Micrometeorology, University of Bayreuth, Germany \\ Received: 27 May 2009 - Published in Atmos. Chem. Phys. Discuss.: 10 August 2009 \\ Revised: 30 November 2009 - Accepted: 8 December 2009 - Published: 11 January 2010
}

\begin{abstract}
The observed rapid climate warming in the Arctic requires improvements in permafrost and carbon cycle monitoring, accomplished by setting up long-term observation sites with high-quality in-situ measurements of turbulent heat, water and carbon fluxes as well as soil physical parameters in Arctic landscapes. But accurate quantification and well adapted parameterizations of turbulent fluxes in polar environments presents fundamental problems in soilsnow-ice-vegetation-atmosphere interaction studies. One of these problems is the accurate estimation of the surface or aerodynamic temperature $T_{(0)}$ required to force most of the bulk aerodynamic formulae currently used. Results from the Arctic-Turbulence-Experiment (ARCTEX-2006) performed on Svalbard during the winter/spring transition 2006 helped to better understand the physical exchange and transport processes of energy. The existence of an atypical temperature profile close to the surface in the Arctic spring at Svalbard could be proven to be one of the major issues hindering estimation of the appropriate surface temperature. Thus, it is essential to adjust the set-up of measurement systems carefully when applying flux-gradient methods that are commonly used to force atmosphere-ocean/land-ice models. The results of a comparison of different sensible heat-flux parameterizations with direct measurements indicate that the use of a hydrodynamic three-layer temperature-profile model achieves the best fit and reproduces the temporal variability of the surface temperature better than other approaches.
\end{abstract}

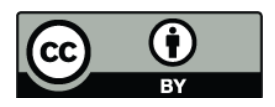

Correspondence to: J. Lüers (johannes.lueers@uni-bayreuth.de)

\section{Introduction}

The surface energy balance is an essential element of the climate in any region of the world, but it takes on added significance in the polar environments, where small changes in the surface energy balance can lead to dramatic changes in the snow and ice cover itself, as well as in the active soil layer of tundra ecosystems. The energy and matter exchange in polar environments - in particular the heat transfer between the surface and atmospheric boundary layer and the carbon balance of tundra ecosystems - is poorly understood (Persson et al., 2002). This is principally because of lack of observations for diagnosing the processes, for quantifying fluxes and for validating numerical models. Satellite data and ground measurements over the past 30 years as well as climate model results have revealed drastic climatic changes in the Arctic (e.g. Moritz et al., 2002; Johannessen et al., 2004; Lindsay and Zhang, 2005; Maslanik et al., 2007; Turner et al., 2007; Kimball et al., 2007; Comiso et al., 2008; Overland et al., 2008; Simmonds et al., 2008).

Energy balance data over snow and sea ice are available from various measurement campaigns, mostly in the Antarctic (e.g. Andreas and Makshtas, 1985; Kottmeier and Belitz, 1987; King, 1990; Handorf et al., 1999; Foken, 1996; King and Anderson, 1994; King et al., 1996). In the Arctic region they are available from the Arctic Ice Dynamics Joint Experiment (AIDJEX) in the 1970s (Untersteiner, 1980), the Marginal Ice Zone Experiments (MIZEX) in 1983, 1985 and 1987 (Horn and Johnson, 1986), the Coordinated Eastern Arctic Experiment (CEAREX) in 1988 (Pritchard et al., 1990), the Leads Experiment (LEADEX) in 1992, and the campaign "The Surface Heat Budget of the Arctic Ocean" (SHEBA) from 1995 to 2002 (Moritz and Perovich, 1996; Andreas et al., 2002; Uttal et al., 2002; Grachev et al., 2007). Spatial and temporal coverage of those experiments

Published by Copernicus Publications on behalf of the European Geosciences Union. 
investigating different types of polar landscapes in the Arctic and Antarctic is still poor, and existing standard climate observations are inadequate to understand and finally model the physical processes. Instead, special measurements addressing complex processes important for the energy budget of polar ecosystems are required (Persson et al., 2002) to allow accurate model validations.

Typically, in many energy balance studies turbulent fluxes of sensible and latent heat and of momentum are computed using parameterizations with uncertain accuracies. Bulk formulas (e.g. Maykut, 1982; Andreas and Makshtas, 1985; Maykut and Perovich, 1987; Guest and Davidson, 1991; Cheng and Launiainen, 1995; Lindsay, 1998; Schröder et al., 2003), are widespread because they allow estimation of the turbulent surface fluxes from routine meteorological measurements (flux-gradient method). Most problems result from uncertainties in the appropriate determination of the bulk aerodynamic transfer coefficients for sensible and latent heat over snow and ice (Louis, 1979; Banke et al., 1980; Overland, 1985; Andreas and Murphy, 1986; Andreas, 2002), the aerodynamic roughness expressed by drag coefficients (Guest and Davidson, 1991) as well as the estimation of the surface roughness lengths (Andreas, 1987) and stability correction terms for the universal functions (e.g. Handorf et al., 1999; Holtslag and DeBruin, 1988; Launiainen, 1995; Grachev et al., 2007).

Especially in the polar region under neutral or stable stratification the energy exchange is influenced by the longlife stable atmospheric boundary layer (Zilitinkevich and Calanca, 2000; Sodemann and Foken, 2004), which can be present for weeks during the polar night and sometimes for days in the transition seasons. Under neutral or stable atmospheric stratification regular turbulent events are rather intermittent and the near surface boundary layer is influenced by gravity waves and partly by topographically induced large eddy or secondary circulation patterns, and is therefore not handled well by the usual bulk parameterizations (Foken, 2008).

More uncertainties arise due to the appearance of a considerably disturbed vertical temperature profile close to the surface, generating a so called narrow inversion layer within the first $1 \mathrm{~m}$ to $3 \mathrm{~m}$ above ground. This prominent phenomenon was described by Sodemann and Foken (2005) in the Antarctic and can be confirmed by this study for an Arctic site. The inaccurate treatment of this disturbed temperature profile results in inaccurate measurements or recalculation of the surface temperature $T_{(0)}$, which is required for most of the bulk parameterizations, and finally yields a significant misestimation of the sensible heat flux.

Nevertheless, bulk formulas are common in sea-ice and ocean models to compute turbulent fluxes (e.g. Maykut and Untersteiner, 1971; Gabison, 1987; Ebert and Curry, 1993; Launiainen and Cheng, 1998). But comparisons of modeled turbulent fluxes with direct measurements are rarely performed (Ruffieux et al., 1995; Launiainen et al., 2001).
One of the latest flux measurement campaigns on Svalbard, the Arctic Turbulence Experiment ARCTEX-2006 (Lüers and Bareiss, 2007a, b; Bareiss and Lüers, 2007), took place in May 2006 in the Kongsfjord region near Ny-Ålesund. This pilot study was intended to compare different measurement techniques (eddy-covariance, laserscintillometry, and gradient tower) and up to date pre- and post-processing methods with classic modeling approaches over tundra ecosystems. Therefore, established quality assessment and quality control (QA/QC) techniques were performed to find the major problems in order to improve the data quality and to adapt the methods to polar conditions (Lüers and Bareiss, 2010). In this study a comparison of different sensible heat-flux parameterizations (Ebert and Curry, 1993; Launiainen and Cheng, 1995; Sodemann and Foken, 2005) with direct measurements using the eddy-covariance approach is presented. Special emphasis is applied to the difficulties in estimating the surface temperature (a) using recalculations from the outgoing infrared radiation measurement (IR) obtained by the BSRN-station at Ny-Ålesund and (b) by an extrapolation of the measured vertical air temperature profile applying the hydrodynamic 3-layer-model (3LM) approach described by Sodemann and Foken (2005). Finally, basic recommendations are given for how to optimally set up the measurement instrumentation and to use QA/QC techniques when applying standard flux-gradient methods.

\section{Data and methods}

From 5 May to 19 May 2006 turbulent flux and meteorological measurements were performed on the monitoring field near Ny-Ålesund at $78^{\circ} 55^{\prime} 24^{\prime \prime} \mathrm{N}, 11^{\circ} 55^{\prime} 15^{\prime \prime}$ E Kongsfjord, Svalbard (Spitsbergen). The ARCTEX-2006 campaign site was located about $200 \mathrm{~m}$ southeast of the settlement on flat snow covered tundra, $11 \mathrm{~m}$ to $14 \mathrm{~m}$ above sea level (Lüers and Bareiss, 2007a, 2010). The permanent sites used for this study consisted of the $10 \mathrm{~m}$ meteorological tower (MT1) of the Alfred Wegener Institute for Polar- and Marine Research (AWI), the international standardized radiation measurement site of the Baseline Surface Radiation Network (BSRN), the radiosonde launch site (RS) and the AWI tethered balloon launch sites TB1 and TB2. The temporary sites (Lüers and Bareiss, 2007a) - set up by the Universities of Bayreuth (UBT) and Trier - were the $6 \mathrm{~m}$ meteorological gradient tower (MT2), the eddy-flux measurement complex (EF), and the scintillometer section (SLS). The ongoing AWI tower MT1 is routinely equipped with two ventilated resistance thermometers and two non-ventilated capacitive humidity sensors as well as two combined wind sensors (cupanemometer and wind vane) at $2 \mathrm{~m}$ and $10 \mathrm{~m}$ height. The height of the fixed-mounted instruments above the surface during the campaign varied with the snow depth. In average the real measurement height of the lower AWI-MT1 sensors was $1.85 \mathrm{~m}$. This height was then used for all parameterizations. 
The UBT tower MT2 offered wind speed measurements using cup-anemometers at five different heights of $0.73 \mathrm{~m}$, $1.42 \mathrm{~m}, 2.37 \mathrm{~m}, 3.85 \mathrm{~m}$, and $5.63 \mathrm{~m}$. At three levels of $0.73 \mathrm{~m}$, $2.37 \mathrm{~m}$, and $5.63 \mathrm{~m}$ above ground ventilated thermometers were mounted. All sensors were sampled once every second and averaged if required over $1 \mathrm{~min}, 5 \mathrm{~min}$ or $30 \mathrm{~min}$ intervals. Additional micrometeorological measurements were necessary to (1) monitor the turbulent fluxes of momentum, and sensible heat during the ARCTEX campaign and (2) to compare these direct measurements with calculated results from simple flux gradient parameterizations. The UBT eddyflux measurement complex EF was equipped with a Campbell Scientific CSAT3 ultra-sonic-anemometer to measure the turbulent variation of all three wind vectors as well as the sonic temperature at $2.4 \mathrm{~m}$ above ground.

The turbulent fluxes obtained were pre- and postprocessed with the internationally standardized (Mauder et al., 2008) QA/QC software package TK2, developed by the Department of Micrometeorology, University of Bayreuth (Mauder and Foken, 2004). TK2 is capable of performing all of the post processing and automatically produces quality assured turbulent fluxes for a station in a single run. It includes all corrections and tests, which are state of the art, and provides a sophisticated quality assessment. Two special quality tests (Foken and Wichura, 1996; Foken et al., 2004), the Steady State test to detect non steady state conditions during the chosen perturbation timescale, and the test on the Integral Turbulence Characteristics (ITC-test) comparing measured integral turbulence characteristics with modeled ones, were applied to the ARCTEX-2006 flux data. The Steady State test proves high quality conditions (classes 1 to 3 ) for $92 \%$ of all $u_{*}$ and $73 \%$ of all buoyancy fluxes (Lüers and Bareiss, 2010). As expected, most of the low-quality classes 7 to 9 occur at periods of very stable atmospheric stratification and very weak values of the friction velocity like on 9 May or during the night from 11 May to 12 May 2006.

In this study, these quality checked sensible heat flux measurements from the EF-complex are compared with bulk formulas that are widely used in atmosphere-ocean/land-ice models for polar regions as described in Ebert and Curry (1993) and Launiainen and Cheng (1995). These approaches easily allow estimation of the turbulent surface fluxes from routine meteorological measurements. The turbulent sensible heat flux $Q_{\mathrm{H}}$ is commonly parameterized using the bulk aerodynamic formula

$Q_{\mathrm{H}}=\rho_{\mathrm{a}} \cdot c_{\mathrm{p}} \cdot C_{\mathrm{H}(z)} \cdot v_{h(z)} \cdot\left(T_{(0)}-T_{(z)}\right)$

over ice or ground, where $\rho_{\mathrm{a}}$ and $c_{\mathrm{p}}$ denote the air density and specific heat capacity of air, $C_{\mathrm{H}(z)}$ the atmospheric heat transfer coefficient or Stanton-number, $T_{(0)}$ the surface or aerodynamic temperature, $T_{(z)}$ and $v_{h(z)}$ the air temperature and wind speed at height $z$. To calculate the latent heat flux $Q_{\mathrm{E}}$ Eq. (1) has to be adapted with the heat of evaporation, the Dalton-number and the water vapor gradient.
In the flux-gradient algorithm used by Ebert and Curry (1993), abbreviated EC93, a stability-dependent $C_{\mathrm{H}}$ (Eqs. 2 and 3) is computed following Louis (1979) using the bulk Richardson-number $R i_{\mathrm{B}}$ as the stratification index and the heat transfer coefficient for neutral conditions above a snow/ice surface $C_{\mathrm{Hn}}=1.3 \times 10^{-3}$ according to Andreas (1987). The Richardson-number is the ratio of shear production to the buoyancy production or destruction of turbulence energy using the characteristic vertical temperature and wind gradients.

Due to a better data base Ebert and Curry (1993) proposed using the value 20 for the fitting parameter $b_{1}$ and not 4.7 as Louis (1979) first assumed. This yields a better agreement between the Universal Functions and the Louis parameterization especially at stable exchange conditions. To estimate the height dependent coefficient $b_{2}$ the suggestion $\left(b_{2}=C_{\mathrm{Hn}} \cdot b_{1} \cdot 1961\right.$, with $\left.z=10 \mathrm{~m}, z_{0}=1.6 \times 10^{-4} \mathrm{~m}\right)$ by Ebert and Curry (1993) was used. This is a slight modification due to the new fitted coefficient $b_{1}$ of the original formula Eq. (4) found by Louis (1979).

$$
\begin{aligned}
& C_{\mathrm{H}}=C_{\mathrm{Hn}} \cdot\left(1-\frac{2 \cdot b_{1} \cdot R i_{\mathrm{B}}}{1+b_{2} \cdot\left|R i_{\mathrm{B}}\right|^{0.5}}\right) R i_{\mathrm{B}}<0, \\
& C_{\mathrm{H}}=C_{\mathrm{Hn}} \cdot\left(1+b_{1} \cdot R i_{\mathrm{B}}\right)^{-2} R i_{\mathrm{B}} \geq 0,
\end{aligned}
$$

$b_{2}=C_{\mathrm{Hn}} \cdot 2 b_{1} \cdot c^{*} \cdot\left(\frac{z}{z_{0}}\right)^{0.5}$

$z \gg z_{0} ; c^{*}=5.3$ (Louis, 1979).

For these $C_{\mathrm{H}}$-estimations the surface temperature $T_{(0)}$ is indirectly addressed through the $R i_{\mathrm{B}}$ number, which is therefore a possible error source.

This is avoided in the heat flux parameterization proposed by Launiainen and Cheng (1995) and Launiainen (1995), abbreviated LC95. It is based on a semi-analytical relationship between the bulk Richardson-number and the Obukhov stability parameter $\zeta=z / L$, which is the dimensionless fraction of the respective measurement height $z(2.4 \mathrm{~m})$ and the Obukhov-length $L$. Universal Functions for momentum $\Psi_{\mathrm{M}}$ and sensible heat $\Psi_{\mathrm{H}}$ from Businger et al. (1971), Dyer (1974), and Högström (1988) for unstable conditions, and for stable conditions the function suggested by Holtslag and De Bruin (1988), are used to derive the bulk transfer coefficients instead. The decisive parameterization of the StantonNumber $C_{\mathrm{H}}$ is formulated as:

$C_{\mathrm{H}}=\alpha_{\mathrm{Hn}} \cdot \kappa^{2} \cdot\left(\ln \frac{z}{z_{0}}-\Psi_{\mathrm{M}}\left(\frac{z}{L}\right)\right)^{-1} \cdot\left(\ln \frac{z}{z_{T}}-\Psi_{\mathrm{H}}\left(\frac{z}{L}\right)\right)^{-1}$,

where $\kappa=0.4$ is the von-Kármán proportion factor, and $\alpha_{\mathrm{Hn}}$ is the turbulent Prandtl-number or the ratio of the eddy diffusivities of heat and momentum in the neutral case, with $\alpha_{\mathrm{Hn}}=1$ if using the integrated Universal Function from Högström (1988). 
The critical issue is the determination of the aerodynamic surface parameters to describe the aerodynamic characteristics and used for the LC95-parameterization. Based on the on-site determined geometric roughness of the snow surface of $0.02 \mathrm{~m}$ the mean scalar roughness of the ARCTEX-2006 fetch area was calculated by the formulae of Andreas (1987) and the neutral drag coefficients by the formulae of Banke et al. (1980).

The aerodynamic roughness $z_{0}$ was estimated to be $0.1 \mathrm{~mm}$ above snow or $0.2 \mathrm{~mm}$ above the patchwork of bare tundra and scattered snow and ice covered areas. These values are determined by extrapolating the semilogarithmic graph of the mean vertical wind profile observed during ARCTEX-2006 and could be confirmed by the sonic-anemometer measurements $(0.12 \mathrm{~mm})$ using the integrated profile equation for momentum at neural conditions, and match the assumption of $0.16 \mathrm{~mm}$ in the EC93parameterization.

If an average $u_{*}$ is known and a snow free case is assumed we recommend for the estimation of $z_{T}$ the use of the simple approach mentioned by Beljaars (1995) or Jacobson (2005) that the roughness parameter for temperature is a ratio of the kinematic viscosity of air to the friction velocity:

$z_{T}=0.4 \cdot \frac{v}{u_{*}}$

This simple estimation of $z_{T}$ is just an example. More advanced methods are presented by e.g. Launiainen (1995), Andreas (1987), Garratt (1992) or King and Anderson (1994). The mean temperature roughness $z_{T}$ during ARCTEX-2006 was defined as $2.9 \times 10^{-5} \mathrm{~m}$ (average $v=$ $1.318 \times 10^{-5} \mathrm{~m}^{2} \mathrm{~s}^{-1}$ and $u_{*}=0.18 \mathrm{~m} \mathrm{~s}^{-1}$ ), thus the dimensionless ratio of $z_{0}$ to $z_{T}$ is around 7, needed by the LC95approach to estimate the stability parameter $\zeta=z / L$ (for the case that no sonic-anemometer data are available) and the bulk transfer coefficients $C_{\mathrm{H}}$ and $C_{\mathrm{E}}$, respectively, if a more or less snow free case is assumed. For the comparison of measured and modeled heat fluxes (Sect. 3.3) both ways, (a) with a distinct ratio of $z_{0}$ to $z_{T}$ assuming snow free tundra surface conditions (rougher surface) and (b) with a ratio equal 1 assuming a full snow covered (smooth) surface were applied to run the LC95-parameterization. But during May 2006 the footprint area of the eddy measurements was either full covered by snow or ice or later predominantly covered by snow (only very small snow free patches). Consequently, the LC95 runs with method (b) results to a better quantitative agreement and were used for the comparison than the runs using method (a).

To force most of the bulk-parameterizations the required surface or aerodynamic temperature $T_{(0)}$ can be derived by applying one of many different approaches. The obvious and more common way is to recalculate $T_{(0)}$ from outgoing long-wave radiation measurements (IR). Available for ARCTEX-2006 were the Eppley pyrgeometer measurements from the BSRN-station using a Kirchhoff emissivity of 0.99 for snow. A more sophisticated approach is to use the hydrodynamic three-layer temperature profile model (3LM) developed originally for flux measurements above sea-water by Foken (1979 and 1984) and first applied above snow in Antarctica by Sodemann and Foken (2005). This approach introduces an advanced profile coefficient $\Gamma$, replacing the product of wind speed and the Stanton- or Dalton-number $C_{\mathrm{H}(z)}$ or $C_{\mathrm{E}(z)}$. This profile coefficient is derived as an integral over the very small $(<1 \mathrm{~mm})$ molecular boundary layer directly connected to the surface, the viscous stability independent buffer layer $(\sim 1 \mathrm{~cm})$ and the stability independent turbulent dynamic sub-layer $(\sim 1 \mathrm{~m})$ using parameterized dimensionless thickness and normalized temperature differences. For heights exceeding $1 \mathrm{~m}$ the stability influence according to the Monin-Obukhov-similarity (Monin and Obukhov, 1954) must be considered. This results in the final formula:

$\Gamma=\frac{\kappa \cdot u_{*}}{\frac{\delta_{T} \cdot u_{*}}{v} \cdot \kappa \cdot \operatorname{Pr}+4 \cdot \kappa+\ln \frac{u_{*} \cdot z}{30 \cdot v}}$,

where $\kappa=0.4$ means the von-Kármán proportion factor, $u_{*}$ the friction velocity, $\operatorname{Pr}=0.71$ the molecular-turbulent Prandtl number, $z$ the height in $\mathrm{m}$ and $v$ the kinematic viscosity of air in $\mathrm{m}^{2} \mathrm{~s}^{-1}$. The term

$\frac{\delta_{T} \cdot u_{*}}{v}=\left\{\frac{6, u_{*} \leq 0.23 \mathrm{~m} \mathrm{~s}^{-1}}{12, u_{*} \geq 0.23 \mathrm{~m} \mathrm{~s}^{-1}}\right\}$

denotes the dimensionless thickness $\delta_{T}$ of 6 or 12 (Foken, 1978) of the integral between the surface and the top of the molecular boundary layer depending on friction velocity and the kinematic viscosity of air. The term $4 \cdot \kappa$ represents the normalized temperature difference of the integral of the buffer layer (Foken, 1984). Its dimensionless thickness is assumed nowadays as 30 , analogous to Eq. (8), but without the $u_{*}$ criterion. Finally, the relation of $\kappa \cdot u_{*} \cdot z$ describes the turbulent exchange coefficient for momentum needed to solve the integral of the third layer. Now we can rewrite Eq. (1) to $\left(Q_{\mathrm{H}}\right.$ in $\left.\mathrm{K} \mathrm{m} \mathrm{s}^{-1}\right)$ :

$Q_{\mathrm{H}}=\Gamma \cdot\left(T_{(0)}-T_{(z)}\right)$ or

$T_{(0)}=\frac{Q_{\mathrm{H}}}{\Gamma}+T_{(z)}$

Air temperature $T_{(z)}$ and wind speed $v_{h(z)}$ at measurement height $z$ are derived for this study from the AWI meteorological gradient tower MT1 at a height of $1.85 \mathrm{~m}$ above the snow surface. 


\section{Results}

\subsection{Disturbed temperature profile close to the surface}

As in detail described by Sodemann and Foken (2005) over the Antarctic shelf ice, a prominent considerably disturbed vertical temperature profile was evident, generating a so called narrow inversion layer close to the surface. During this event the near ground air mass ( 1 to $3 \mathrm{~m}$ ) is thermally decoupled from the more or less undisturbed vertical air temperature profile above this narrow inversion (Fig. 1a). Hence, the temperature gradient in this decoupled layer likely did not reflect the heat fluxes measured within the Prandl-layer above. This reminds of the known errors caused by a mechanical internal boundary layer forced by a discontinuity in surface roughness.

While the mean vertical wind profile during ARCTEX2006 corresponds to quite undisturbed measurements, the mean temperature profile shows a distinctive temperature increase of $0.35 \mathrm{~K}$ from the cold snow surface to a height of around $2 \mathrm{~m}$, before it changed to the "normal" overlying profile. The shown profiles case A and B in Fig. 1 are means of selected profiles based on half hourly air temperature and wind speed values measured between 7 May and 19 May. For case A every 30 -min temperature profile fitting to the shape of a strong inversion forced by rapid, strong surface cooling was selected (36\% of all cases). For case B times with a strong surface warming were selected (50\% of all cases), showing a sharp temperature decrease in the first $1 \mathrm{~m}$ and than a sharp increase until $2.4 \mathrm{~m}$ above ground. The results of paired two-sample t-tests applied for both cases A and B assure that the temperature means e.g. between $0 \mathrm{~m}$ and $2.4 \mathrm{~m}$ above ground are different with $99 \%$ confidence.

At low solar altitudes, mostly between 05:00 and 08:00 or 17:00 and 22:00 CET, a temperature difference of up to $2 \mathrm{~K}$ is quite common within this near surface thermocline layer (Fig. 1a, case A). Under extreme conditions with strong and rapid surface cooling the temperature difference could exceed $5 \mathrm{~K}$. Conversely, if a surface warming occurs mostly around noon due to (shortwave) radiation forcing or (independent of the time of day) due to an increase in incoming infrared-radiation (gathering clouds), the temperature profile in the first $1 \mathrm{~m}$ to $3 \mathrm{~m}$ is much more disturbed as shown in Fig. 1a, case B. Obviously in most of the cases in May 2006 this near ground inversion never completely disappeared. For $36 \%$ of the time between 7 May and 19 May this strong inversion (case A) is well developed and for $50 \%$ of the time we get profiles of case B mostly in the transition period around noon (surface warming). Like Sodemann and Foken (2005) have described for the Antarctic Neumayer Station advection or drainage wind flows seems to be not the explanation for Ny-Ålesund as well. Only for two events (e.g. on 9 May, between $18 \mathrm{~h} \mathrm{CET} \mathrm{and} \mathrm{midnight} \mathrm{CET)} \mathrm{drainage} \mathrm{wind} \mathrm{flows}$ down the slopes of the nearby Zeppelin Mountain range were observable, proofed by the wind speed and wind direction
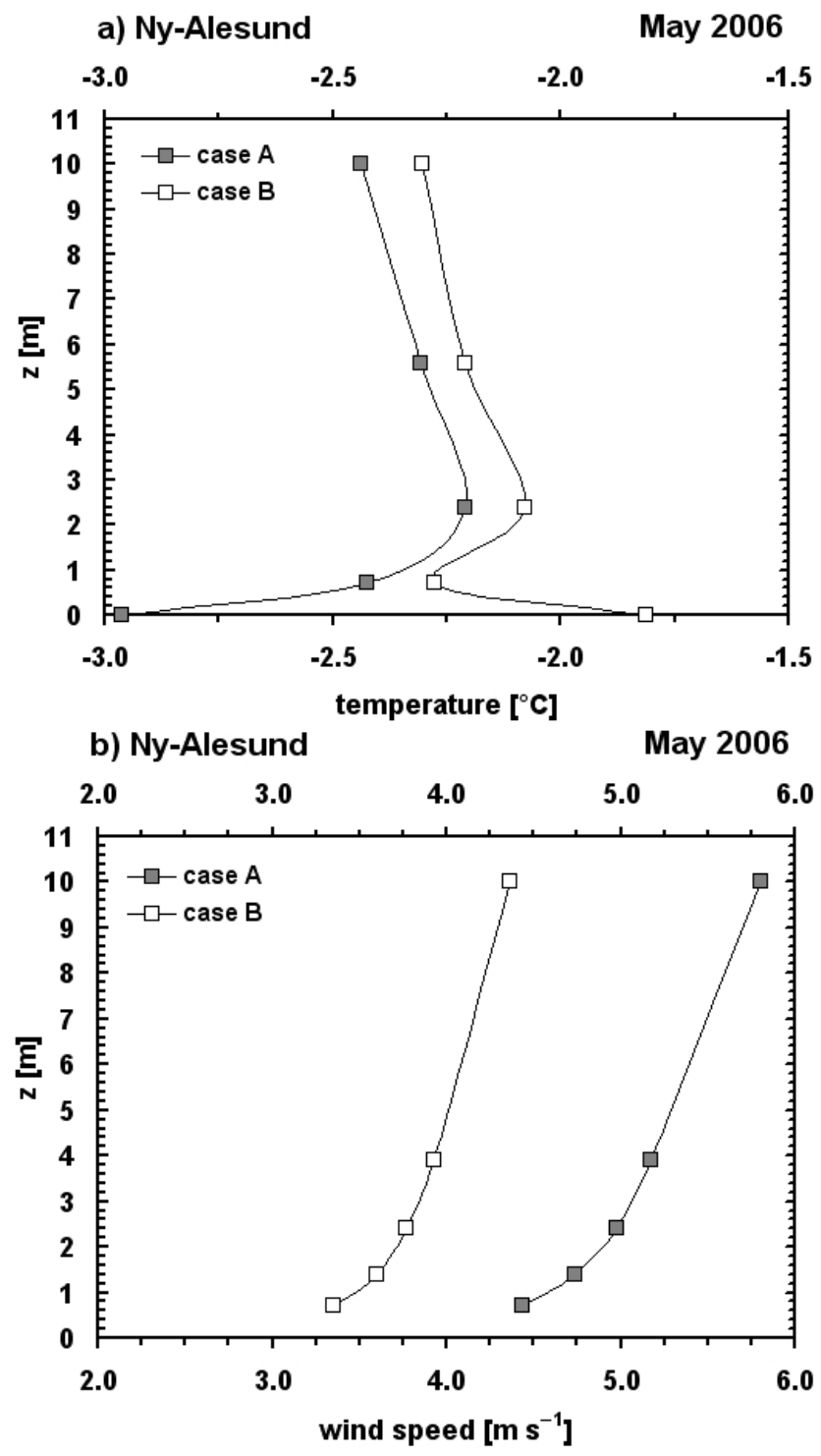

Fig. 1. Mean vertical profiles of air temperature (a) and wind speed (b) for two separate cases A and B between 7 May and 19 May 2006, as observed at the UBT meteorological gradient tower MT2. Case A reflects strong surface cooling and a sharp thermocline inversion within just 1 or $2 \mathrm{~m}$ above ground mostly occurring between 05:00 and 08:00 or 17:00 and 22:00 CET (36\% of all cases). Case B occurs mostly around noon (09:00 to 16:00 CET) indicating a disturbed air temperature profile caused by surface warming (50\% of all cases). Ny-Ålesund (Svalbard), ARCTEX-2006 campaign.

profiles measured at the gradient tower close to the eddy-flux station (Bareiss and Lüers, 2007; Lüers and Bareiss, 2007b). And the mean wind profiles corresponding to case A and B (Fig. 1b) showing no katabatic effects as well. 


\subsection{Estimation of surface temperature}

Considering the problem of estimating the "true" snow/ice or tundra surface temperature $T_{(0)}$, significant differences between the IR-derived or 3LM-extrapolated surface temperature occur during ARCTEX-2006 that are typical for early spring tundra surface situations. The most relevant process based distinction can be observed at times mainly around noon with a short, intermittent but developed unstable exchange situation and positive directed sensible heat fluxes as observed on 13 May or 16 May over a closed snow surface. For these cases the extrapolated surface temperature $T_{(0)}$ using the 3LM-approach considerably exceeds (physically incorrect) zero degrees Celsius (yields values up to $+4{ }^{\circ} \mathrm{C}$ ) but corresponding to the measured positive sensible heat flux. However, the air temperature above the still snow and ice covered ground remains below $0{ }^{\circ} \mathrm{C}$ and the IR-derived surface temperature of the snow surface reaches and remains at zero degrees, corresponding to the melting point of snow. The reason for this overestimation of $T_{(0)}$ is that the effect of the disturbed temperature profile is not considered in the 3LM-paramterisation. The observed positive heat flux is caused due to the rapid surface warming and/or the appearance of short but distinct free convection events (Lüers and Bareiss, 2010) happening in the whole footprint area of the EF-station. Another noticeable difference between both $T_{(0)}$ estimations appears at times mostly with overcast skies with a cloud-base height lower than $2000 \mathrm{~m}$ accompanied by a high percentage of diffuse radiation. For these cases the IR-derived surface temperature is significantly warmer $(\sim 1 \mathrm{~K})$ than the 3LM-extrapolated surface temperature. This corresponds with negative sensible flux directions and with a relatively small difference between the outgoing and the incoming infrared radiation resulting in a longwave radiation balance loss of around $30 \mathrm{~W} \mathrm{~m}^{-2}$. In the opposite case (clear sky conditions) this difference is three times greater (average longwave radiation energy loss of $95 \mathrm{~W} \mathrm{~m}^{-2}$ ). This effect leads, especially during the "night time" with a relatively weak shortwave forcing, to a visible, significant increase of the surface temperature, where it has a greater influence on the IR-derived than on the 3LM-extrapolated $T_{(0)}$ estimations. Finally, the ARCTEX-data show a visible tendency that for cases with light or developed unstable atmospheric exchange conditions the estimated surface temperature derived from the outgoing infrared radiation is colder than the 3LM-extrapolated value. These situations occur mostly around noon to early afternoon.

In case of a near surface inversion layer and decoupled exchange conditions between the first $1 \mathrm{~m}$ to $3 \mathrm{~m}$ and the Prandtl-layer above this thermal boundary, the IR-derived surface temperature is significantly warmer than the extrapolated value. This situation is quite common in the evening or morning hours.

The correctness of the IR-derived or the 3LM-extrapolated values depend on the quality of the outgoing infrared radiation measurements and/or the quality of the sonicanemometer measurements. For the former, the conditions (snow or snow free, or a patchwork) of the ground area visible to the downward directed sensor influence the Kirchhoff's emissivity $\varepsilon$ or the cooling or warming of the surface especially during freeze-melt cycles. For the latter, for example, the snowdrift effects (Foken, 1998; Lüers and Bareiss, 2010) and the existence of the near surface inversion layer which leads to decoupled exchange conditions, are the error sources with the greatest effect. During ARCTEX-2006 the surface temperature could be measured using an infrared thermometer and the radiation measurements of the Baseline Surface Radiation Network situated nearby. Both methods showed lot measurement errors in the data sets. For the next step, the comparison of modeled and measured heat fluxes, it was necessary to present the IR-radiation independent method to determine the surface temperature $T_{(0)}$ using eddy-covariance data and the 3LM-approach to create an independent and consistent data set for surface temperature to run the parameterizations of EC93 and LC95.

\subsection{Comparison of measured and modeled heat fluxes}

As a consequence of calculating the sensible heat flux using the LC95-parameterization (Eqs. 1 and 5) over snow (smooth surface) with these differently derived surface temperatures, the correlation between both results doesn't fit very well (Fig. 2a) using non checked data. It is mandatory to eliminate periods with incorrect flux values, but the decision as to what is wrong or right is not simple and in most cases not obvious. As the first step, at least an elimination of obvious errors for periods with snowdrift or precipitation effects on the sonic-anemometer and an elimination of bad values due to the sonic-anemometer QA/QC procedure (e.g. the spike detection or the Steady State test to detect non steady state conditions not fulfilling the eddy-covariance assumptions), is helpful to increase the correlation of both flux estimations (Fig. 2b).

But the previously mentioned surface temperature distinctions still remain and they produce significant but more or less evenly distributed scatter close to the line of identity. And, especially in cases where the IR-derived temperature is higher than the $3 \mathrm{LM}$-extrapolated value (e.g. during the appearance of the inversion layer or overcast longwave radiation forced periods), the resulting sensible heat flux is - due to smaller temperature gradients - underestimated if the IR-derived temperature is used as input to the LC95parameterization. This error can be as high as 30\% to $40 \%$ compared to the sensible heat flux measured (EF) in $2.4 \mathrm{~m}$ above ground and in most cases above this inversion layer (Fig. 3a).

Running the LC95-parameterization with the 3LMextrapolated snow surface temperature as input produces a significantly better agreement with the measured data (Fig. 3b) without any significant exaggerations. This is not 

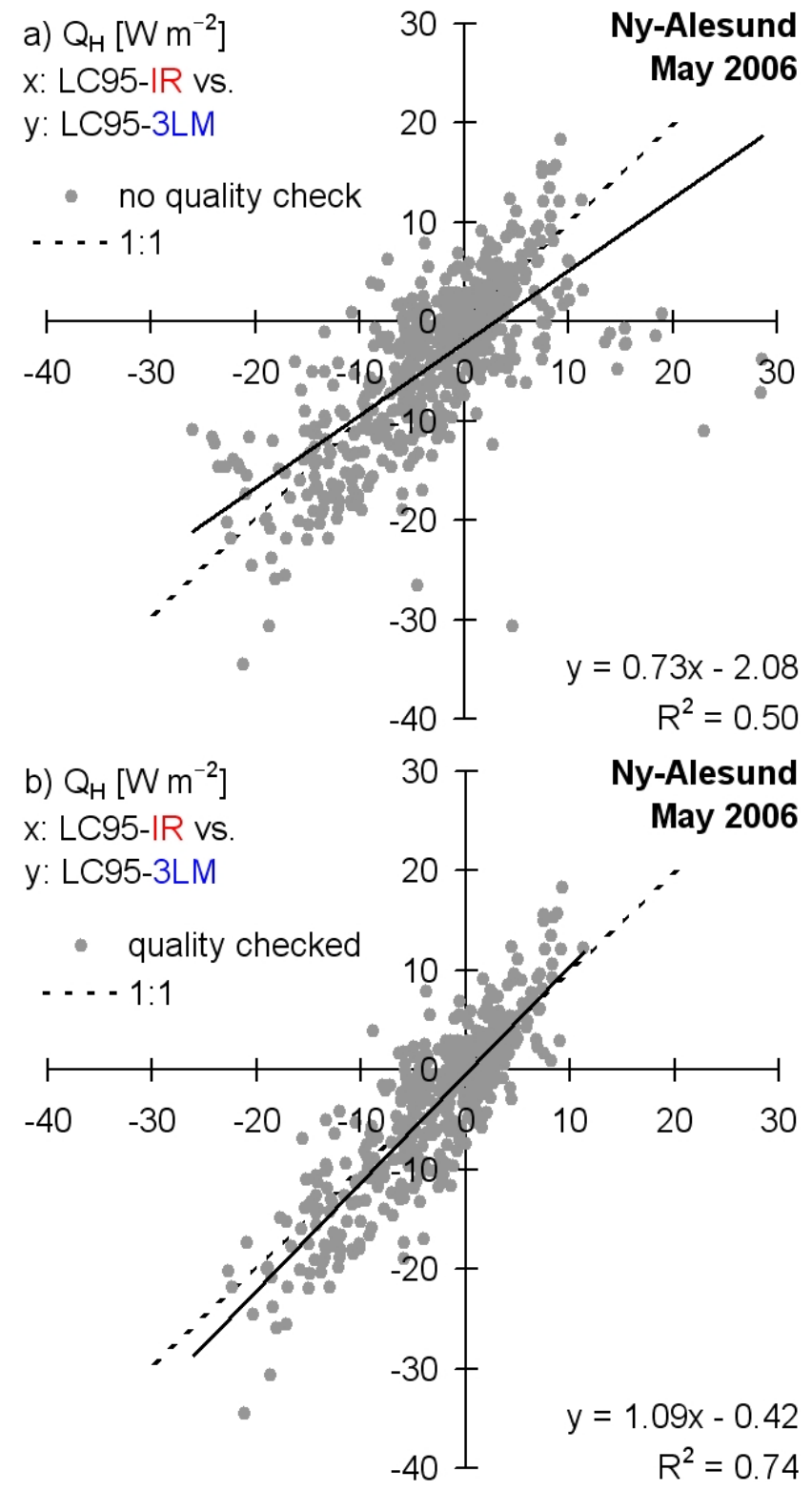

Fig. 2. Linear correlation between sensible heat flux $Q_{\mathrm{H}}\left[\mathrm{W} \mathrm{m}^{-2}\right]$ calculated with the LC95-parameterization (Launiainen and Cheng, 1995) using the IR-derived (IR) or the 3-layer-model-extrapolated (3LM) surface temperature $T_{(0)}$ as input: (a) unfiltered values, (b) quality checked values, elimination of the periods with nonstationary conditions (steady state test) and snowdrift or precipitation effects on the sonic-anemometer from 7 May to 19 May 2006. Ny-Ålesund (Svalbard), ARCTEX-2006 campaign. unexpected because the 3LM-approach includes not only the turbulent layer (like the bulk approach with extrapolation of the turbulent profile to $\left.T_{(0)}\right)$ but also the buffer and molecular layer that means it is physically more exact (Bjutner, 1974; Foken, 1984; Mangarella et al., 1972, 1973; Oertel, 2004). Second, to calculate the profile coefficient $\Gamma$, only quite reliable data of the friction velocity $u_{*}(\mathrm{Eq} .7)$ and $Q_{\mathrm{H}}$ flux data are needed and used (Eq. 10). And accordingly, this extrapolation of the aerodynamic vertical temperature profile ignores the falsifying effect (on the real fluxes) of the disturbed temperature profile much better than the IR-derived approach. To remove some scatter and to gain better results for $T_{(0)}$, it is recommended not only to use QA/QC checked flux-measurements to solve Eq. (9) but to slightly smooth them before use (moving average, subset size of 3 or 5).

The decision to run the LC95-parameterization implying a full snow cover, a mix, or snow free tundra could also be crucial. Especially in the spring or autumn transition periods the snow/ice-cover conditions of the tundra soil change rapidly. Thus, the aerodynamic surface parameters $z_{0}$ and $z_{T}$ have to be adjusted properly. Regarding the already small sensible heat fluxes during the early arctic spring, the calculated differences of $Q_{\mathrm{H}}$ running the LC95-parameterization with a smooth snow surface ( $z_{0}$ and $z_{T}$ in the same range) or a rougher tundra surface (distinct ratio of $z_{0}$ to $z_{T}$ ), ranging at Ny-Ålesund in May between 3\% and mostly 10\%, and on some occasions (primarily around noon or afternoon) these differences show up to $40 \%$ greater $Q_{\mathrm{H}}$ and greater $Q_{\mathrm{E}}$ if computing with a rougher surface. But if the snow conditions in the immediate area are known, e.g. by a routinely operating imaging system (Web-cam), the possibility offered by the LC95-parameterization of adjusting these aerodynamic surface parameters in a very simple way could lead to quite realistic results.

Finally, the comparison of the measured and quality checked eddy-flux data with the Ebert and Curry (1993) approach (Eqs. 1-3) following Louis (1979) using the bulk Richardson-number $R i_{\mathrm{B}}$ and the IR-derived $T_{(0)}$ (Fig. 4a) shows the same poor relationship as the comparison between EF and LC95-IR (Fig. 3a). However, it is evident that the EC93-IR approach strongly overestimates the sensible heat flux. This effect doesn't disappear (Fig. 4b) if the 3LMextrapolated $T_{(0)}$ is used as input (EC93-3LM). The direct relation seems less scattered but in contrast to the similar case above (Fig. 3b) the strong overestimation of the EC93parameterization is still inadequate. Principally, the EC93parameterization allows an adjustment of only the measurement height $z$ and the roughness length $z_{0}$, but - provided there is a sufficient dataset - one has to inconveniently recalculate the multiple regression coefficients (Eqs. 2-4) valid for the site and time of interest. 


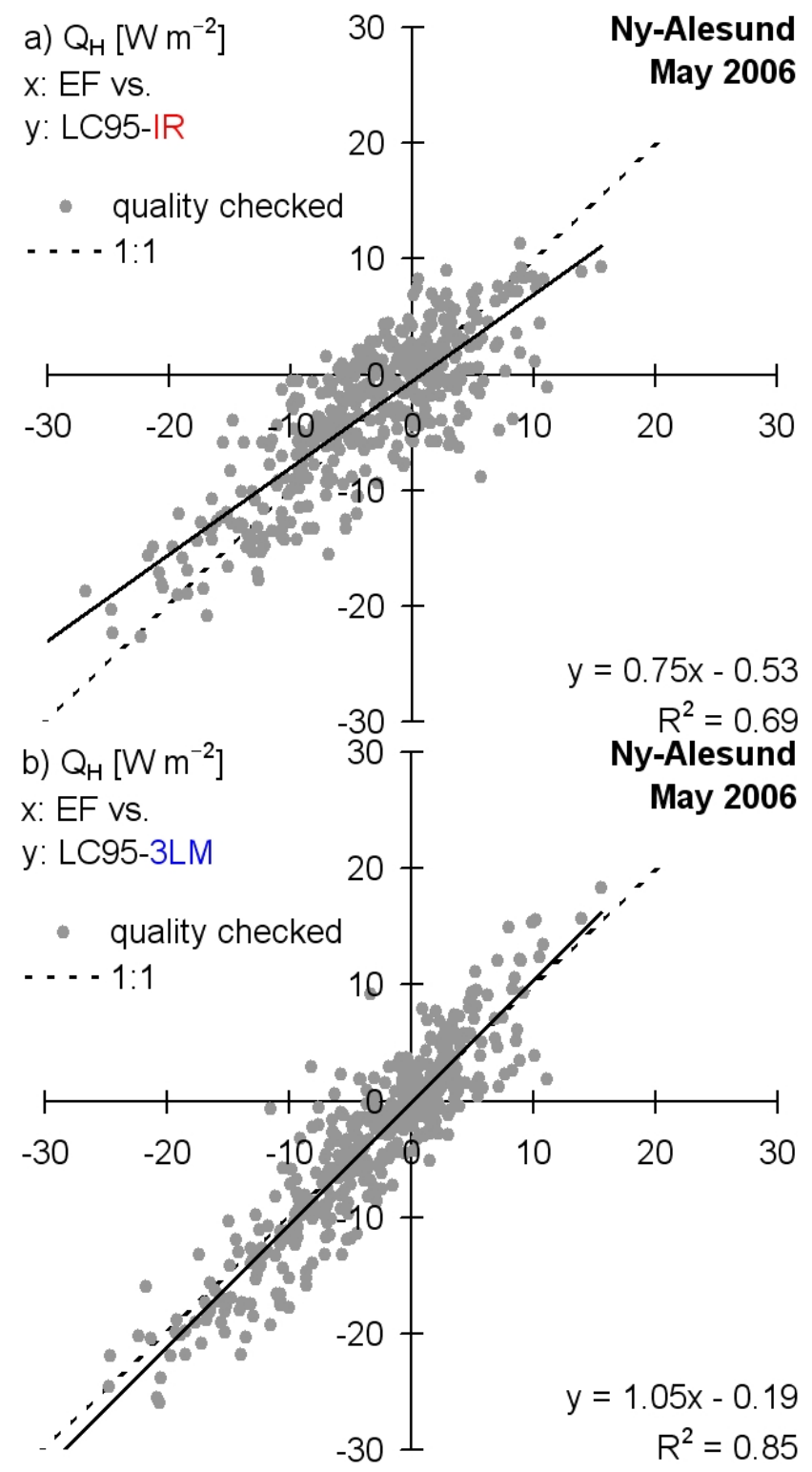

Fig. 3. Linear correlation of the sensible heat flux $Q_{\mathrm{H}}\left[\mathrm{W} \mathrm{m}^{-2}\right]$ measured with a sonic-anemometer applying the eddy-covariance method (EF), and calculated with the LC95-parameterization (Launiainen and Cheng, 1995) over a snow surface using (a) the IRderived (IR) and b) the 3-layer-model-extrapolated (3LM) surface temperature $T_{(0)}$ as input. Quality checked values, elimination of the periods with non-stationary conditions (steady state test) and snowdrift or precipitation effects on the sonic-anemometer, 7 May to 19 May 2006. Ny-Ålesund (Svalbard), ARCTEX-2006.

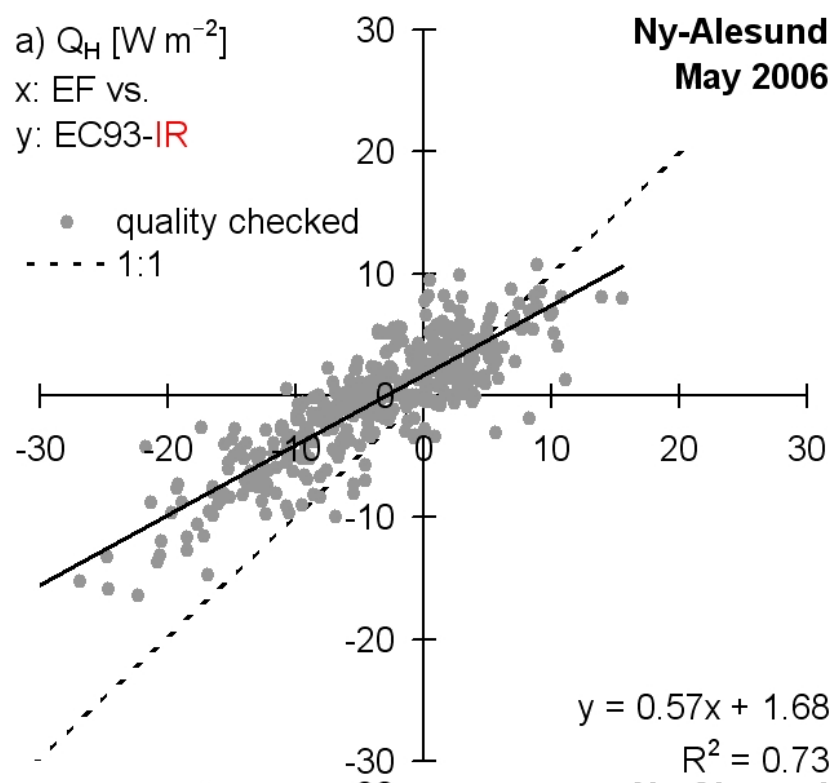

b) $Q_{H}\left[W m^{-2}\right]$

$\mathrm{x}$ : EF vs.

$y:$ EC93-3LM

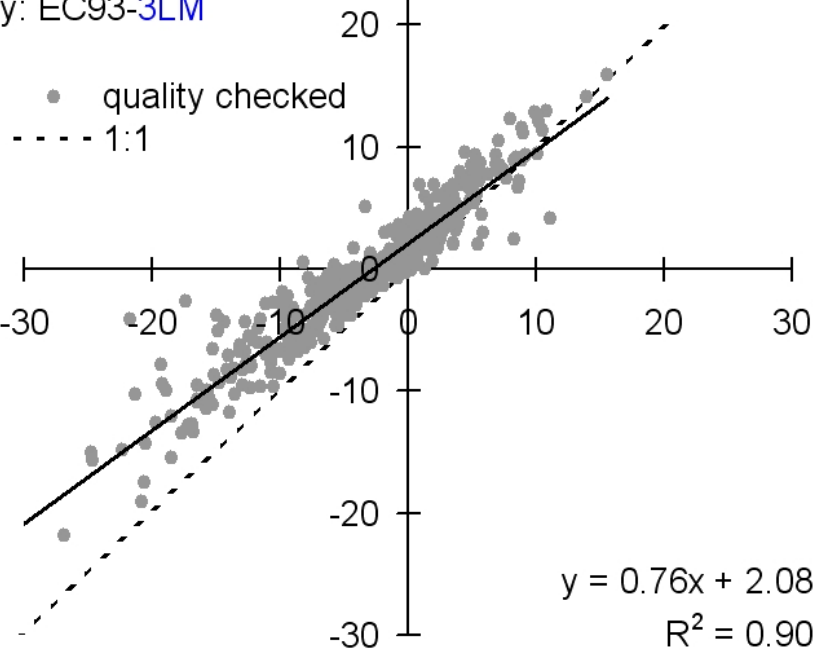

Fig. 4. Linear correlation of the sensible heat flux $Q_{\mathrm{H}}\left[\mathrm{W}, \mathrm{m}^{-2}\right]$ measured with a sonic-anemometer applying the eddy-covariance method (EF), and calculated with the EC93-parameterization (Ebert and Curry, 1993) over a snow surface using (a) the IR-derived (IR) and (b) the 3-layer-model-extrapolated (3LM) surface temperature $T_{(0)}$ as input. Quality checked values, elimination of the periods with non-stationary conditions (steady state test) and snowdrift or precipitation effects on the sonic-anemometer, 7 May to 19 May 2006. Ny-Ålesund (Svalbard), ARCTEX-2006. 


\section{Conclusions}

Detailed information on typical temperature profiles gained from the ARCTEX-2006 campaign has shown a significant influence on the estimation of the real surface temperature due to the existence of a considerably disturbed vertical temperature profile close to the surface, generating a strong inversion layer within the first $1 \mathrm{~m}$ to $3 \mathrm{~m}$ above ground, and due to snow or ice melting processes, both common during the arctic spring season. This disturbed vertical temperature profile appears frequently ( $40 \%$ of the time of the experiment) in the early morning and/or late evening hours caused by a rapid surface cooling. It decouples the first $1 \mathrm{~m}$ to $3 \mathrm{~m}$ above ground from the atmospheric exchange above the inversion, and it disturbs the vertical temperature profile in a manner resembling the effect of a mechanical internal boundary layer. Snow or ice melting processes, caused by short but distinct unstable atmospheric exchange situations or by freeconvection events (Lüers and Bareiss, 2010), occur mostly around noon or early afternoon. Both effects can yield a considerably misleading estimation of the surface temperature and thus to an incorrect temperature gradient, to wrong Richardson-numbers and finally to incorrect heat fluxes. Especially during the existence of such an inversion layer over a snow or partly snow covered arctic tundra, the use of the surface temperature $T_{(0)}$ recalculated from outgoing long-wave radiation measurements (IR-derived) to force the common bulk-aerodynamic formulas does not work well.

If independent and quality checked direct measured sensible (and latent) heat and momentum (or frictions velocity $u_{*}$ ) fluxes are available, we recommend the use of the advanced profile coefficient $\Gamma$ to gain a more adapted effective surface temperature estimation applicable for soil-physical or micrometeorological parameterizations regarding studies in permafrost landscapes. This coefficient is based on the hydrodynamic three-layer temperature profile model (Eqs. 7 and 10) developed by Foken (1979 and 1984). It replaces the product of wind speed and the Stanton- or Dalton-numbers $C_{\mathrm{H}(z)}$ or $C_{\mathrm{E}(z)}$ without using the Richardson-number which is otherwise required by the commonly used approaches following Louis (1979).

Consequently, the $R i_{\mathrm{B}}$ independent Launiainen and Cheng (1995) approach (Eq. 5) together with the 3LMextrapolated surface temperature inserted into the general bulk-aerodynamic formula (Eq. 1) produces an acceptable agreement compared with the measured sensible heat flux, without the strong overestimation calculated with the Ebert and Curry (1993) approach (Eqs. 2 and 3) following Louis (1979).

The advantage of the surface temperature extrapolated using measured $Q_{\mathrm{H}}$ and $u_{*}$ and the hydrodynamic three-layer model is a realistic and reliable reproduction of the temporal variability of the surface temperature independent of the falsifying effect of the disturbed vertical temperature profile. Additionally, this estimation method is not directly in- fluenced by the snow cover conditions present, which is the case, when $T_{(0)}$ is recalculated from the outgoing longwave radiation (Kirchhoff emissivity). The disadvantage is that under polar conditions during spring time the eddy-flux measurements obtained by applying the eddy-covariance method are frequently disturbed e.g. by the snowdrift and precipitation effects or due to the intermittent turbulence character causing violations of eddy-covariance assumptions (steady state conditions, flux-variance similarity).

Another issue is that during the spring season, over a closed snow surface at times (mostly around noon or early afternoon) with a short, intermittent but well developed turbulence and positive (upward) directed heat fluxes, the 3LMextrapolated surface temperature is noticeably overestimated compared to the IR-derived value (snow-surface temperature remains around $0^{\circ} \mathrm{C}$ during melting) which could lead, for both kinds of $C_{\mathrm{H}}$ or $Q_{\mathrm{H}}$ parameterization, to a complementary, but slight, overestimation of the resulting fluxes.

As a final point, if the measurement height of the eddycovariance system is not in the appropriate layer above the decoupling inversion layer to capture the full turbulence spectra, or the wrong measurement heights are set on the meteorological gradient tower with respect to the air temperature (or humidity) differences required for the bulk methods, the derived heat fluxes may be inadequately incorrect. That means perhaps that a rearrangement of measurement heights according to the change of seasons is necessary.

Overall, it is strongly recommended, especially regarding the installment of long-term eddy-flux measurement sites (Westermann et al., 2008, 2009) in an Arctic permafrost region, to investigate the near surface temperature profile e.g. with a combination of a single eddy-covariance complex and gradient tower systems with ventilated thermohygrometers and cup-anemometers, and to perform a detailed analysis of the variability of the snow and/or tundra soil surface conditions. This is essential to find the appropriate instrumentation setup as a compromise between the effect of the disturbance of the temperature profile and the conflicting task of finding an acceptable fetch and the desired footprint area.

Acknowledgements. The authors thank all of those from the French-German Arctic Research Base led by the Alfred Wegener Institute for Polar and Marine Research (AWI) and the Institut polaire franais Paul mile Victor (IPEV) for their efforts to succeed with the ARCTEX-2006 campaign, especially the station leader Rainer Vockenroth. We also appreciated the logistic support of the staff of the Kingsbay Company at Ny-Ålesund. Very welcome was the major support and wise counsel of Thomas Foken, head of the Dept. of Micrometeorology, Univ. of Bayreuth. Many thanks go also to Jo Olesch (technical support) and to Alfred Helbig. This study was funded by the Deutsche Forschungsgemeinschaft under reference number DFG-FO 226/11-1.

Edited by: J. W. Bottenheim 


\section{References}

Andreas, E. L.: A theory for the scalar roughness and the scalar transfer coefficients over snow and sea ice, Bound.-Lay. Meteorol., 38, 159-184, 1987.

Andreas, E. L.: Parameterizing scalar transfer over snow and ice: A review, J. Hydrometeorol., 3, 417-432, 2002.

Andreas, E. L. and Makshtas, A. P.: Energy exchange over Antarctic Sea ice in the spring, J. Geophys. Res., 90(C10), 7199-7212, 1985.

Andreas, E. L. and Murphy, B.: Bulk transfer coefficients for heat and momentum over leads and polynyas, J. Phys. Oceanogr., 16, 1875-1883, 1986.

Andreas, E. L., Guest, P. S., Persson, P. O. G., Fairall, C. W., Horst, T. W., Moritz, R. E., and Semmer, S. R.: Near-surface water vapor over polar sea ice is always near ice saturation, J. Geophys. Res., 107(C10), 8033, doi:10.1029/2000JC000411, 2002.

Banke, E. G., Smith, S. D., and Anderson, R.: Drag coefficient at AIDJEX from sonic anemometer measurements, Sea-Ice Processes and Models, edited by: Pritchard, R. S., University of Washington Press, Seattle, 430-442, 1980.

Bareiss, J. and Lüers, J.: Direct measurements of turbulent fluxes in the near surface environment at high latitudes applying the eddy-covariance method - Arctic Turbulence Experiment 2006 - PART 3, Aerological measurements during the ARCTEX 2006 campaign, 2-20 May 2006, Work Report Vol. 33, University of Bayreuth, Dept. of Micrometeorology, Internet: ISSN 16148926, 90 pp., 2007.

Beljaars, A. C. M.: The parametrization of surface fluxes in large scale models under free convection, Q. J. Roy. Meteor. Soc., 121, 255-270, 1995.

Bjutner, E. K.: Teoreticeskij rascet soprotivlenija morskoj poverchnosti (Theoretical calculation of the resistance at the surface of the ocean), in: Processy perenosa vblizi poverchnosti razdela okean - atmosfera (Exchange processes near the ocean - atmosphere interface), edited by: Dubov, A. S., Gidrometeoizdat, Leningrad, 66-114, 1974.

Businger, J. A., Wyngard, J. C., Izumi, Y., and Bradley, E. A.: Flux profile relationships in the atmospheric surface layer, J. Atmos. Sci., 28, 181-189, 1971.

Cheng, B. and Launiainen, J.: A simple non-iterative algorithm for calculating turbulent bulk fluxes in diabatic conditions over water, snow/ice and ground surface, Report Series in Geophysics, 33, Dept. of Geophysics, University of Helsinki, 12 pp., 1995.

Comiso, J. C., Parkinson, C. L., Gersten, R., and Stock, L.: Accelerated decline in the Arctic sea ice cover, Geophys. Res. Lett., 35, L01703, doi:10.1029/2007GL031972, 2008.

Dyer, A. J.: A review of flux profile relationship, Bound.-Lay. Meteorol., 7, 363-372, 1974.

Ebert, E. E. and Curry, J. A.: An intermediate one-dimensional thermodynamic sea ice model for investigating ice-atmosphere interactions, J. Geophys. Res., 98(C6), 10085-10109, 1993.

Foken, T.: Vorschlag eines verbesserten Energieaustauschmodells mit Berücksichtigung der molekularen Grenzschicht der Atmosphäre, Z. Meteorol., 29, 32-39, 1979.

Foken, T.: The parametrisation of the energy exchange across the air-sea interface, Dynam. Atmos. Oceans, 8, 297-305, 1984.

Foken T.: Turbulenzexperiment zur Untersuchung stabiler Schichtungen, Ber. Polarforsch., 188, 74-78, 1996
Foken, T.: Bestimmung der Schneedrift mittels Ultraschallanemometern, Ann. Meteorol., 37, 451-452, 1998.

Foken, T.: Micrometeorology, Springer, Heidelberg, 308 pp., 2008.

Foken, T. and Wichura, B.: Tools for quality assessment of surfacebased flux measurements, Agr. Forest. Meteorol., 78, 83-105, 1996.

Foken, T., Göckede, M., Mauder, M., Mahrt, L., Amiro, B. D., and Munger, J. W.: Post-field data quality control, in: Handbook of Micrometeorology: A Guide for Surface Flux Measurement and Analysis, edited by: Lee, X., Massman, W., and Law, B., Kluwer, Dordrecht, 181-208, 2004.

Foken, T., Kitajgorodskij, S. A., and Kuznecov, O. A.: On the dynamics of the molecular temperature boundary layer above the sea, Bound.-Lay. Meteorol., 15, 289-300, 1978.

Gabison, G.: A thermodynamic model of the formation, growth, and decay of first-year sea ice, J. Glaciol., 33, 105-119, 1987.

Garratt, J. R.: The Atmospheric Boundary Layer., Cambridge Univ. Press, 316 pp., 1992.

Grachev, A. A., Andreas, E. L., Fairall, C. W., Guest, P. S., and Persson, P. O. G.: SHEBA flux-profile relationships in the stable atmospheric boundary layer, Bound.-Lay. Meteorol., 124, 315333, 2007.

Guest, P. S. and Davidson, K. L.: The aerodynamic roughness of different types of sea ice, J. Geophys. Res., 96(C3), 4709-4721, 1991.

Handorf, D., Foken, T., and Kottmeier, C.: The stable atmospheric boundary layer over an Antarctic ice sheet, Bound.-Lay. Meteorol., 91, 165-189, 1999.

Högström, U.: Non-dimensional wind and temperature profiles in the atmospheric surface layer: A reevaluation, Bound.-Lay. Meteorol., 42, 55-78, 1988.

Holtslag, A. A. M. and De Bruin, H. A. R.: Applied modeling of the nighttime surface energy balance over land, J. Appl. Meteorol., 27, 689-704, 1988.

Horn, D. A. and Johnson G. L.: MIZEX East: Past Operations and Future Plans, Oceanus, 29(1), 66-72, 1986.

Jacobson, M. Z.: Fundamentals of Atmospheric Modelling, Cambridge Univ. Press, 813 pp., 2005.

Johannessen, O. M., Bengtsson, L., Miles, M. W., Kuzmina, S. I., Semenov, V. A., Alekseev, G. V., Nagurnyi, A. P., Zakharov, V. F., Bobylev, L. P., Pettersson, L. H., Hasselmann, K. F., and Cattle, A. P.: Arctic climate change: observed and modelled temperature and sea-ice variability, Tellus A, 56, 328-341, 2004.

Kimball, J. S., Zhao, M., McGuire, A. D., Heinsch, F. A., Clein, J., Calef, M., Jolly, W. M., Kang, S., Euskirchen, S. E., McDonald, K. C., and Running, S. W.: Recent climate driven increases in vegetation productivity for the western Arctic: Evidence of an acceleration of the northern terrestrial carbon cycle, Earth Interact., 11(4), 1-30, doi:10.1175/EI180.1, 2007.

King, J. C.: Some measurements of turbulence over an Antarctic ice shelf, Q. J. Roy. Meteor. Soc., 116, 379-400, 1990.

King, J. C. and Anderson, P. S.: Heat and water vapor fluxes and scalar roughness lengths over an Antarctic ice shelf, Bound.-Lay. Meteorol., 69, 101-121, 1994.

King, J. C., Anderson, P. S., Smith, M. C., and Mobbs, S. D.: The surface energy and mass balance at Halley, Antarctica during winter, J. Geophys. Res., 101(D14), 19119-19128, 1996.

Kottmeier, C. and Belitz, H.-J.: Meteorological research using a high mast on the Antarctic ice shelf, Mar. Technol., 1, 5-10, 
1987.

Launiainen, J.: Derivation of the relationship between the Obukhov stability parameter and the bulk Richardson Number for fluxprofile studies, Bound.-Lay. Meteorol., 76, 165-179, 1995.

Launiainen, J. and Cheng, B.: A simple non-iterative algorithm for calculating turbulent bulk fluxes in diabatic conditions over water, snow/ice and ground surface, Report Series in Geophysics, 33, Dept. of Geophysics, University of Helsinki, 1995.

Launiainen, J. and Cheng, B.: Modelling of ice thermodynamics in natural water bodies, Cold Reg. Sci. Technol., 27, 153-178, 1998.

Launiainen, J., Cheng, B., Uotila, J., and Vihma, T.: Turbulent surface fluxes and air-ice coupling in the Baltic Air-Sea-Ice Study (BASIS), Ann. Glaciol., 33, 237-242, 2001.

Lindsay R. W.: Temporal Variability of the energy balance of thick Arctic pack ice, J. Climatol., 11, 313-333, 1998.

Lindsay, R. W. and Zhang, J.: The thinning of arctic sea ice, 19882003: Have we passed a tipping point?, J. Climatol., 18, 48794894, 2005.

Louis, J.-F.: A parametric model of vertical eddy fluxes in the atmosphere, Bound.-Lay. Meteorol., 17, 187-202, 1979.

Lüers, J. and Bareiss, J.: Direct measurements of turbulent fluxes in the near surface environment at high latitudes applying the eddy-covariance method - Arctic Turbulence Experiment 2006 - PART 1, Technical documentation of the ARCTEX 2006 campaign, 2-20 May 2006, Work Report Vol. 31, University of Bayreuth, Dept. of Micrometeorology, Internet: ISSN 16148926, 32 pp., 2007a.

Lüers, J. and Bareiss, J.: Direct measurements of turbulent fluxes in the near surface environment at high latitudes applying the eddy-covariance method - Arctic Turbulence Experiment 2006 PART 2, Near surface measurements during the ARCTEX 2006 campaign, 2-20 May 2006, Work Report Vol. 32, University of Bayreuth, Dept. of Micrometeorology, Internet: ISSN 16148926, 75 pp., $2007 b$.

Lüers, J. and Bareiss, J.: Direct near surface measurements of sensible heat fluxes in the arctic tundra applying eddy-covariance and laser scintillometry - The Arctic Turbulence Experiment 2006 on Svalbard (ARCTEX-2006), Theor. Appl. Climatol., submitted, 2010.

Mangarella, P. A., Chambers, A. J., Street, R. L., and Hsu, E. Y.: Laboratory and field interfacial energy and mass flux and prediction equations, J. Geophys. Res., 77, 5870-5875, 1972

Mangarella, P. A., Chambers, A. J., Street, R. L., and Hsu, E. Y.: Laboratory studies of evaporation and energy transfer through a wavy air-water interface, J. Phys. Oceanogr., 3, 93-101, 1973.

Maslanik, J. A., Fowler, C., Stroeve, J., Drobot, S., Zwally, J., Yi, D., and Emery W.: A younger, thinner Arctic ice cover: Increased potential for rapid, extensive sea-ice loss, Geophys. Res. Lett., 34, L24501, doi:10.1029/2007GL032043, 2007.

Mauder, M. and Foken, T.: Documentation and Instruction Manual of the Eddy Covariance Software Package TK2, Work report Vol. 26, University of Bayreuth, Dept of Micrometeorology, Internet: ISSN 1614-8926, 45 pp., 2004.

Mauder, M., Foken, T., Clement, R., Elbers, J. A., Eugster, W., Grünwald, T., Heusinkveld, B., and Kolle, O.: Quality control of CarboEurope flux data - Part 2: Inter-comparison of eddycovariance software, Biogeosciences, 5, 451-462, 2008, http://www.biogeosciences.net/5/451/2008/.
Maykut, G. A.: Large-scale heat exchange and ice production in the central Arctic, J. Geophys. Res., 87(C8), 7971-7984, 1982.

Maykut, G. A. and Perovich, D. K.: The role of shortwave radiation in the summer decay of a sea ice cover, J. Geophys. Res., 92(C7), 7032-7044, 1987.

Maykut, G. A. and Untersteiner, N.: Some results from a timedependent thermodynamic model of sea ice, J. Geophys. Res., 76, 1550-1575, 1971.

Monin, A. S. and Obukhov, A. M.: Osnovnye zakonomernosti turbulentnogo peremesivanija $\mathrm{v}$ prizemnom sloe atmosfery, Trudy geofiz inst AN SSSR, 24(151), 163-187, 1954.

Moritz, R. E. and Perovich, D. K.(Eds.): Suface Heat Budget of the Arctic Ocean Science Plan, ARCSS/OAII Report Number 5, University of Washington, Seattle, 64 pp., 1996.

Moritz, R. E., Bitz, C. M., and Steig, E. J.: Dynamics of recent climate change in the Arctic, Science, 297, 1497-1502, 2002.

Oertel, H. (Ed.): Prandtl's essentials of fluid mechanics, Springer, New York, VII, 723 pp., 2004.

Overland, J. E.: Atmospheric boundary layer structure and drag coefficient over sea ice, J. Geophys. Res., 90(C5), 9029-9049, 1985.

Overland, J. E., Wang, M., and Salo, S.: The recent Arctic warm period, Tellus A, 60, 589-597, 2008.

Persson, O. P. G., Fairall, W., Andreas, E. L., and Guest, P. S.: Measurements near the Atmospheric Surface Flux Group tower at SHEBA: Near-surface conditions and surface energy budget, J. Geophys. Res., 107(C10), 8045, doi:10.1029/2002JC000705, 2002.

Pritchard, R. S., Bailey, S. H., Browne, C. M., Coon, M. D., Hoefke, D., Knoke, G. S., Lau, P. A., Taylor, B. J., Hibler III, W. D., Hopkins, M., Onstott, R. G., Schuchman, R. A., O'Hara, S. H., McPhee, M. G., Van Leer, J. C., Davidson, K. L., Guest, P. S., Curtin, T. B., Overland, J. E., Bell, D. L., Bosworth, H. W., Meese, D. A., Gow, A. J., Perovich, D. K., Tucker, W. B., Colony, R., Grenfell, T. C., Martin, S., and Wettlaufer, J. S.: CEAREX Drift Experiment, EOS, Transactions of the American Geophysical Union, 71(40), 1115-1118, 1990.

Ruffieux, D., Persson, P. O., Fairall, C. W., and Wolfe, D. E.: Ice pack and lead surface energy budgets during LEADEX 1992, J. Geophys. Res., 100, 4593-4612, 1995.

Schröder, D., Vihma, T., Kerber, A., and Brümmer, B.: On the parameterization of turbulent surface fluxes over heterogeneous sea ice surfaces, J. Geophys. Res., 108(C6), 3195, doi:10.1029/2002JC001385, 2003.

Simmonds I., Burke C., and Keay K.: Arctic climate change as manifest in cyclone behavior, J. Climatol., 21(22), 5777-5796, 2008.

Sodemann, H. and Foken, T.: Empirical evaluation of an extended similarity theory for the stably stratified atmospheric surface layer, Q. J. Roy. Meteor. Soc., 130, 2665-2671, 2004.

Sodemann, H. and Foken, T.: Special characteristics of the temperature structure near the surface, Theor. Appl. Climatol., 80, 81-89, 2005.

Turner, J., Overland, J. E., and Walsh, J. E.: An Arctic and Antarctic perspective on recent climate change, Int. J. Climatol., 27(3), 277-293, doi:10.1002/joc.1406, 2007.

Untersteiner, N.: AIDJEX Review, in: Sea Ice Processes and Models, edited by: Pritchard, R. S., University of Washington, Seattle, 3-11, 1980. 
Uttal, T., Curry, J. A., McPhee, M. G., Perovich, D. K., Moritz, R. E., Maslanik, J. A., Guest, P. S., Stern, H. L., Moore, J. A., Turenne, R., Heiberg, A., Serreze, M. C, Wylie, D. P., Persson, O. G., Paulson, C. A., Halle, C., Morison, J. H., Wheeler, P. A., Makshtas, A., Welch, H., Shupe, M. D., Intrieri, J. M., Stamnes, K., Lindsey, R. W., Pinkel, R., Pegau, W. S., Stanton, T. P., and Grenfeld, T. C.: The surface heat budget of the Arctic Ocean, Bull. Am. Meteorol. Soc., 83, 255-275, 2002.

Westermann, S., Boike, J., Piel, K., and Lüers, J.: Long-term monitoring of sensible and latent heat fluxes using eddy covariance at a high Arctic permafrost site in Svalbard, Norway, in: Ninth International Conference on Permafrost 2008: Extended Abstracts Part III, edited by: Kane, D. L. and Hinkel, K. M., Institute of Northern Engineering, University of Alaska Fairbanks, USA, 341-342, 2008.
Westermann, S., Lüers, J., Langer, M., Piel, K., and Boike, J.: The annual surface energy budget of a high-arctic permafrost site on Svalbard, Norway, The Cryosphere, 3, 245-263, 2009, http://www.the-cryosphere-discuss.net/3/245/2009/.

Zilitinkevich, S. S. and Calanca, P.: An extended similarity theory for the stably stratified atmospheric surface layer, Q. J. Roy. Meteor. Soc., 126, 1913-1923, 2000. 